\title{
Correction to: Rock physics analysis as a tool for enhancing characterization of Niger Delta deep water sands
}

\author{
Oluwaseun Daniel Akinyemi ${ }^{1}$ Michael Ayuk Ayuk ${ }^{1}$
}

Published online: 22 February 2022

(c) Saudi Society for Geosciences 2022

Correction to: Arabian Journal of Geosciences (2022) 15:98 https://doi.org/10.1007/s12517-021-09370-8

In this article the author names were incorrectly given as "Akinyemi, Oluwaseun Daniel, Ayuk, Michael Ayuk" but should have been "Oluwaseun Daniel Akinyemi, Michael Ayuk Ayuk".

The original article has been corrected.

The original article can be found online at https://doi.org/10.1007/ s12517-021-09370-8.

$\triangle$ Oluwaseun Daniel Akinyemi

akinscodaniel@gmail.com

Michael Ayuk Ayuk

ayukmike2003@yahoo.com

1 Department of Applied Geophysics, Federal University of Technology, Akure, Nigeria 